\title{
Development of a Tractor Drawn Turmeric Planter
}

\author{
A. Gbabo ${ }^{1}$, C. P. Muogbo ${ }^{2}$ and Ibrahim M. Gana ${ }^{3 *}$ \\ ${ }^{1}$ Department of Agricultural \&Bioresources Engineering, Federal University of Technology Minna, \\ Niger State, Nigeria \\ Email: agidides $[A T]$ yahoo.com
}

${ }^{2}$ Department of Agricultural \&Bioresources Engineering, Federal University of Technology Minna, Niger State, Nigeria

\author{
${ }^{3}$ Department of Agricultural \& Bio-environmental Engineering, Federal Polytechnic Bida, \\ Niger State, Nigeria \\ ${ }^{*}$ Corresponding author's email: ganaibro74 [AT] yahoo.com
}

\begin{abstract}
Planting of turmeric has been a challenge to the farmers in Nigeria due to the absence of planting machine. The farmers are left to the traditional method of planting with hoes and cutlasses. This method is time consuming, labour intensive, associated with human drudgery and a high demand for human energy. As a result, a mechanical planter was designed and fabricated. The main objective of the study is to develop and evaluate the performance of a tractor- drawn turmeric planter. The planter was designed, fabricated and tested in the Agricultural and Bioresources Department of The Federal University of Technology, Minna. It consists of a ground drive wheel, hopper, metering system furrow opener, residue cutting edge, furrow closing device press wheel and power transmission mechanism. The performance tests of the fabricated machine were carried out using three levels of turmeric rhizome lengths $(30 \mathrm{~mm}, 45 \mathrm{~mm}$ and $60 \mathrm{~mm})$ at three levels of operational speeds $(8 \mathrm{~km} / \mathrm{h} 10 \mathrm{~km} / \mathrm{h}$ and $12 \mathrm{~km} / \mathrm{h}$ ). The results revealed that there was no steady pattern in the increase or decrease of miss index with increase in turmeric rhizome length and machine operational speed. The highest percentage turmeric rhizome miss index of $35 \%$ was recorded for turmeric rhizome length of $30 \mathrm{~cm}$ at machine operational speed of $10 \mathrm{~km} / \mathrm{h}$ whereas the lowest percentage turmeric rhizome miss index of $15 \%$ was obtained for turmeric rhizome length of $60 \mathrm{~cm}$ at the machine operational speed of $12 \mathrm{~km} / \mathrm{h}$. The machine operational speed and size of the turmeric rhizomes affect the field capacity of the machine. The highest capacity of $0.96 \mathrm{ha} / \mathrm{h}$ was recorded at the highest operational speed of $12 \mathrm{~km} / \mathrm{h}$. The lowest field capacity of $0.63 \mathrm{ha} / \mathrm{h}$ was recorded at the lowest machine speed of $8 \mathrm{~km} / \mathrm{h}$. The developed machine could reduce drudgery involved in manual turmeric planting and save about substantial amount of labour and operating time.
\end{abstract}

Keywords— Development, testing, tractor-drawn turmeric, planter

\section{INTRODUCTION}

Turmeric (Curcuma longa linn) is a stem tuber crop. It belongs to the same family as ginger (Zingiberaceae) and grows in the same hot and humid tropical climate. The rhizome is deep bright yellow in colour. In Nigeria, turmeric is cultivated mostly on subsistent bases in about 19 states [1]. The underground rhizome impacts a distinctive flovour to food but it is also used to provide food with a deep indelible orange colour [2]. Modern medicine has begun to recognize its importance, as indicated by the over 3000 publications dealing with turmeric that came out within the last 25 years [3]. Nutritional analysis showed that $100 \mathrm{~g}$ of turmeric contains $390 \mathrm{kcal}, 10 \mathrm{~g}$ total fat, $3 \mathrm{~g}$ saturated fat, $0 \mathrm{mg}$ cholesterol, $0.2 \mathrm{~g}$ calcium, $0.26 \mathrm{~g}$ phosphorous, $10 \mathrm{mg}$ sodium, $2500 \mathrm{mg}$ potassium, $47.5 \mathrm{mg}$ iron, $0.9 \mathrm{mg}$ thiamine, 0.19 $\mathrm{mg}$ riboflavin, $4.8 \mathrm{mg}$ niacin, $50 \mathrm{mg}$ ascorbic acid, $69.9 \mathrm{~g}$ total carbohydrates, $21 \mathrm{~g}$ dietary fiber, $3 \mathrm{~g}$ sugars, and $8 \mathrm{~g}$ protein [4] and [5]. Planting of turmeric has been a challenge to the farmers in Nigeria due to the absence of planting machine. The farmers are left to the traditional method of planting with hoes and cutlasses. This method is time consuming, labour intensive, associated with human drudgery and a high demand for human energy. It was noted that "time is the essence of farming" and whatever help shorten the time required for planting will help overcome the effect of adverse weather [6]. To achieve food security through large scale production (Mechanization) of crops with high potentials/prospects such as turmeric, there is much need to provide a planting aid to Nigerian farmers to alleviate their suffering. The recent climatic change which results in delayed early rain and short duration of annual rainfall affects the 
maturity of the turmeric rhizomes due to the long time taken in manual planting of turmeric. In most cases, turmeric does not attain 7 - 9 months maturity before the end of the rainy season due to the delay as a result of time (duration) spent in the use of manual planting method. With the above stated reasons, the development of a tractor drawn turmeric planter became necessary. The developed implement is expected to improve the timeliness and efficiency of operation as well as reduce drudgery and cost of turmeric production. The aim of this research work therefore, is to develop a tractor-drawn turmeric planter.

\section{MATERIALS AND METHODS}

\subsection{Design analysis}

The following design analyses were carried out to determine and select the various machine parts:

1. Determination of the minimum width of planter

The minimum width of the planter required to cover 8 hectares per day at operational speed of $10 \mathrm{~km} / \mathrm{h}$ was estimated using equation 1 as reported by [6]

$C_{T}=v \times w$

Where $C_{T}$ is the theoretical capacity, with operational time of 8 hours in a day $\left(\mathrm{m}^{2} / \mathrm{h}\right)$, $\mathrm{S}$ is the speed of operation (m/h), $\mathrm{w}$ is the implement working width (m)

2. Determination of hopper dimensions and capacity

The volume of the hopper was determined as reported by [6] and is gives as

$V=\frac{\mathrm{S}_{\mathrm{R}}}{\mathrm{n} \times \mathrm{BD}}$

Where $\mathrm{V}$ is the volume of the hopper $\left(\mathrm{m}^{3}\right), \mathrm{S}_{\mathrm{R}}$ is the seeding rate of turmeric rhizome $(\mathrm{kg} / \mathrm{h}), \mathrm{n}$ is the number of refilling per hectare, BD is the bulk density $\mathrm{kg} / \mathrm{m}^{3}$

3. Design of rhizome seed metering device

The number of holes on the metering device was determined as reported by [7], as follows:

$\mathrm{N}_{\mathrm{g}}=\frac{\pi \mathrm{D}_{\mathrm{W}}}{\mathrm{i} \times \mathrm{x} \mathrm{x}}$

Where, $\mathrm{D}_{\mathrm{w}}$ is the diameter of the drive wheel, $\mathrm{i}$ is the drive ratio, $\mathrm{x}$ is the intra raw spacing (m)

4. Determination of the angular speed of the drive wheels (rpm)

The angular speed of drive wheel was determined as reported by [8] and is given as

$V=\pi D N_{W}$

Where $\mathrm{V}=$ operational speed $(\mathrm{m} / \mathrm{h}), \mathrm{D}=$ diameter of drive wheel $(0.6 \mathrm{~m}), \mathrm{Nw}=$ rotational speed of drive wheel (rpm)

5. Determination of the shear strength of the planter drive wheels

This was determined in other to select materials of appropriate thickness for the wheel thereby avoiding failure by crumbling. The following equation as reported by [7] and was used to analyse the shear strength of the drive wheel.

$$
\tau=\frac{\mathrm{T}}{2 \mathrm{~A} \mathrm{t}_{\mathrm{w}}}
$$

Where, $\tau$ is the shear strength of the wheel, $T$ is the torque provided by the wheel $(\mathrm{N} / \mathrm{m}), A$ is the area of the wheel based on the median diameter of the wheel $\left(\mathrm{m}^{2}\right), \mathrm{t}_{\mathrm{w}}$ is the thickness of the wheel $(\mathrm{m}), \mathrm{r}$ is the outer radius of the wheel $(\mathrm{m})$

6. Determination of the torque of the planter's Wheel

The torque of the planter's wheel is essential in estimating the power that is transmitted to the metering shaft and it was calculated as reported by [7] and is gives as

$T_{W}=\mathrm{K}_{\mathrm{w}} \times \mathrm{W}_{\mathrm{w}} \times \mathrm{R}_{\mathrm{w}}$

Where: $\mathrm{T}_{\mathrm{w}}=$ torque of the wheel, $\mathrm{K}_{\mathrm{w}}=$ rolling resistance coefficient of wheel $(0.3$ for metallic wheel $)$, $\mathrm{W}_{\mathrm{p}}=\mathrm{Weight}_{\mathrm{w}}$ the drive wheel, $\mathrm{R}_{\mathrm{w}}=$ Radius of the wheel

7. Determination of the diameter of wheel shaft and metering device shaft

The minimum shaft diameter of the wheel shaft was determined as reported by [10] and is gives as

$d^{3}=\frac{16}{S_{\mathrm{g}} \pi} \sqrt{\left(\mathrm{K}_{\mathrm{b}} \mathrm{M}_{\mathrm{b}}\right)^{2}+\left(\mathrm{K}_{\mathrm{t}} \mathrm{M}_{\mathrm{t}}\right)^{2}}$ 
Where, $\mathrm{d}$ is the diameter of shaft $(\mathrm{m}), \mathrm{S}$ is the allowable shear stress $\left(40 \times 10^{6} \mathrm{Nm}^{2}\right.$ for shaft with key way), $\mathrm{K}_{\mathrm{b}}$ is the combined shock and fatigue factor applied to bending moment, $\mathrm{K}_{\mathrm{t}}$ is the combined shock and fatigue factor applied to twisting moment, $\mathrm{M}_{\mathrm{b}}$ is the maximum bending moment, $\mathrm{Mt}$ is the twisting moment (196.12Nm)

\section{Determination of the implement draft}

Draft is an important factor in determining implement power requirement. According to [11], average draft requirements can be estimated using Equation 8:

\section{$D_{I}=\mathrm{F}_{\mathrm{i}}\left(\mathrm{A}+\mathrm{Bv}+\mathrm{Cv}^{2}\right) \mathrm{wd}+\mathrm{R}$}

Where, $D_{I}$ is the implement draft $(N), F_{i}$ is the dimensionless texture adjustment factor, $\mathrm{i}$ is the 1 for fine, 2 for medium and 3 for coarse texture soils, A, B and C is the implement specific constants, $\mathrm{v}$ is the travel speed, $\mathrm{km} / \mathrm{h}, \mathrm{w}$ is the implement working width, $(\mathrm{m})$, $\mathrm{d}$ is the tillage depth, $\mathrm{cm}$ (1.0 for minor tillage tools and seeders), $\mathrm{R}$ is the range of power requirement due to differences in machine design, machine adjustment and crop conditions,

But $\mathrm{w}=$ inter row spacing $\times$ number of rows

From ASAE standards, following are the values: (for row crop planter which are drawn type but seeding only)

$\mathrm{F}_{1}=\mathrm{F}_{2}=\mathrm{F}_{3}=1.0, \mathrm{~A}=900, \mathrm{~B}=\mathrm{C}=0.0, \mathrm{v}=10.0 \mathrm{~km} / \mathrm{h}, \mathrm{w}=1.0 \times 2=2.0 \mathrm{~m}, \mathrm{~d}=1.0$ for seeders and $\mathrm{R}=25 \%$

9. Determination of Power requirement of the implement

Power transmitted through the drive wheel is essential in the designing of the chain drive arrangement. This to ensure that the torque generated will be able to move the metering mechanism. This was obtained using equation 9 as reported by [9]

$\mathrm{p}_{\mathrm{w}}=\frac{2 \pi \mathrm{N}_{\mathrm{w}} \mathrm{T}_{\mathrm{w}}}{60}$

Where, Pw is the power transmitted through the wheel (W), Nw is the speed of the wheel (rpm), Tw is the torque of the wheel $(\mathrm{Nm})$

\subsection{Description of the machine}

1. Machine Frame: This is the skeletal structure of the planter on which all other components are mounted. It was constructed from $75 \mathrm{~mm}$ x $75 \mathrm{~mm}$ x 6 mm carbon steel angle iron. Provisions are made for the 3-point hitching linkages for tractor connection to the machine. During road transportation and on displacement from one field to another, the whole frame is fully mounted on the tractor but during planting operation the planters frame is supported by drive wheel. The structure of frame is as shown in the Figure 1 and Plate 1.

2. Hopper: the cane seed hopper was made from $1.5 \mathrm{~mm}$ thick mild steel sheet. It has a trapezoidal shape (340mm $\mathrm{x}$ $340 \mathrm{~mm})$ top and $(70 \mathrm{~mm} \times 40 \mathrm{~mm})$ lower end. A rubber seal was fixed round the lower end to avoid bruising the rhizomes. It also reduced friction between the rotating metering device and the edge of the hopper and holds the turmeric rhizomes temporarily for planting as the machine is drawn along on the field. The hopper is as shown in Figure 1 and Plate 1.

3. Metering device: This was constructed in a circular disc. The circular disc has six grooves of $70 \mathrm{~mm} \times 60 \mathrm{~mm} x$ $50 \mathrm{~mm}$. The disc is slightly touching the hopper standing vertically above the metering device. This is to ensure that the rhizomes fall into the grooves of the metering system. The power generated by the ground wheel rotates the metering system through a chain transmission. The metering disc on rotation drops the rhizome into the delivering system. The metering device is as shown Figure 1 and Plate 1.

4. Delivery system: The delivering system is as shown in figure 4, its upper part was made of flat stainless plate curved in a frustum shape. The upper end of the plate was fastened to the frame and passed through under the metering system. The lower end of the flat plate was fastened into a 3 inches PVC pipe. The 400mm length PVC terminated behind the furrow opener and was suspended by a circular metallic ring formed with $8 \mathrm{~mm}$ rod. The delivering channel is as shown in Figure 1 and Plate 1.

5. Furrow opener: the furrow opener of this planter is adjustable point type as shown in Figure 1 and Plate 1 . The adjustment was provided to ensure control of $5-10 \mathrm{~cm}$ planting depth as recommended in the agronomic practice of turmeric production. It was made from $8 \mathrm{~mm}$ thick mild steel flat bar and has horizontal V shape with a sharp edge attached to serve as residue cutting device. The $\mathrm{V}$ shape of the furrow opener prevents soil from falling back into created furrow. It creates furrow before the turmeric rhizome is discharged from the delivery channel. It is fastened to the machine frame using $17 \mathrm{~mm}$ size standard bolts and nuts.

6. Furrow closing device: The furrow closing device was designed from a $6 \mathrm{~mm}$ thick mild steel flat bar to form an expanded horizontal $U$ - shape as shown Figure 1 and Plate 1. A $6 \mathrm{~mm}$ thick mild steel angular bar with holes at the lower end for height adjustments was braced perpendicular to the planter frame downward. A similar angular bar was braced to the U - shape closing device and fastened to the perpendicular angular bar with bolts and nuts.

7. The press wheel: The press wheel was constructed in the shape of a car rim. The diameter of the wheel is $200 \mathrm{~mm}$ with the two-edge rolling on the ground while the center curve inward. The inward curved was designed to allow some 
quantity of soil to be packed and pressed on top of the turmeric rhizome for good sprouting. It also ensures that the air spaces around the seed inside the soil are covered. The press wheel is shown in Figure 1 and Plate 1.

8. Ground drive wheel: wheels of larger diameters are to reduce rolling resistance especially in the case of traction wheels. The circumference of the drive wheel was formed with $12 \mathrm{~mm}$ mild steel rod as shown in Figure 1 and Plate 1 . An angular mild steel bar of $4 \mathrm{~mm}$ was used to brace the two circular flat bar at an intervals of $50 \mathrm{~mm}$ round the drive wheel. A 12mm rod was used to design the spokes. These spokes are used to support the center bushing or hub. The spokes are arranged in such a way that they braced the circular circumference and also give it necessary radial support. The two wheels are connected to the two shafts which are suspended in two sets of bearing. The wheels transmit power obtained by the pull from the tractor.

9. Power Transmission System: The power transmission system (Figure 1 and Plate 1) performs the work of reducing the ground speed of the tractor to a permissible level that is suitable for the operation of the turmeric rhizome metering system. It is comprised of chain and two sprockets of predetermined sizes. A big sprocket (42 teeth) fitted to the shaft of the drive wheel and a smaller one (15 teeth) connected to the shaft that was fastened to the frame of the planter with two pillow bearings. From that point, power was taken to the metering device shaft with the aid of chain and two sprockets (34 teeth). Chain and sprockets are used to transmit power in the drive so as to prevent power loss during transmission.

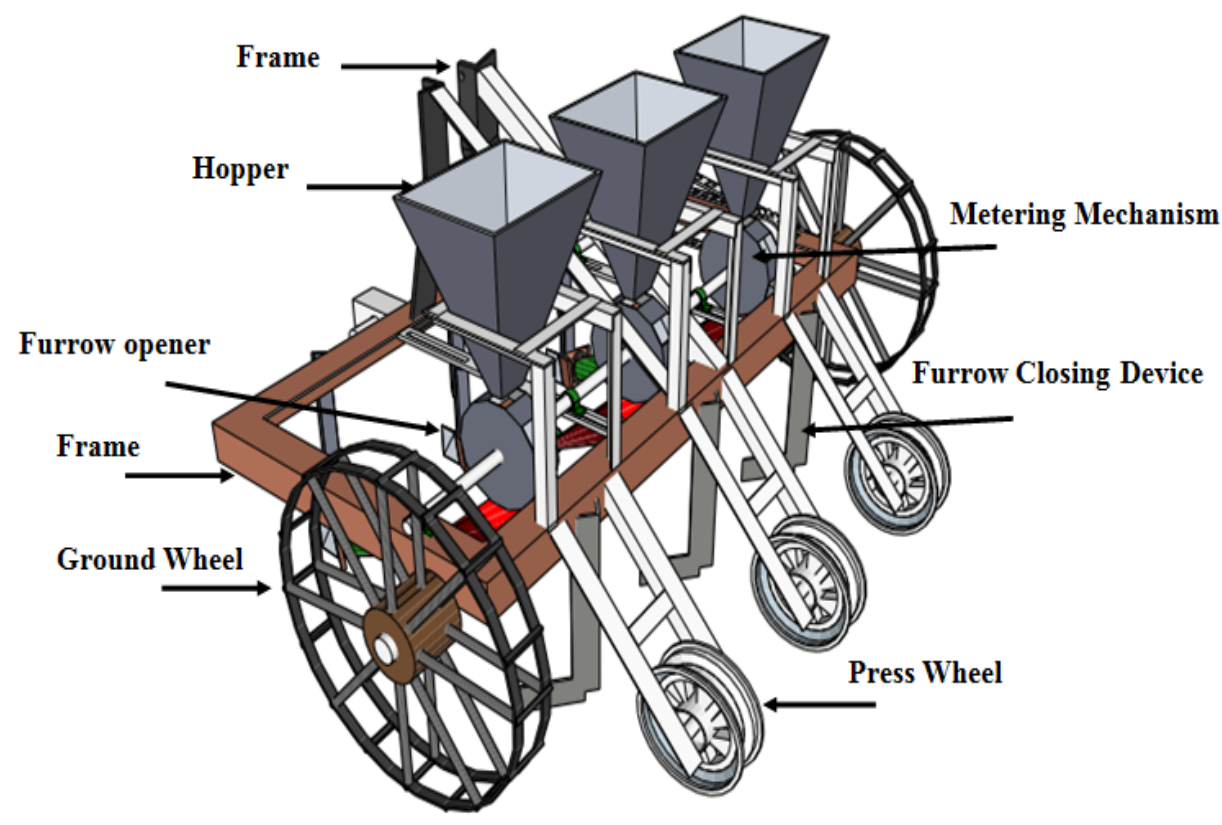

Figure 1: The 3D drawing of the seed planter

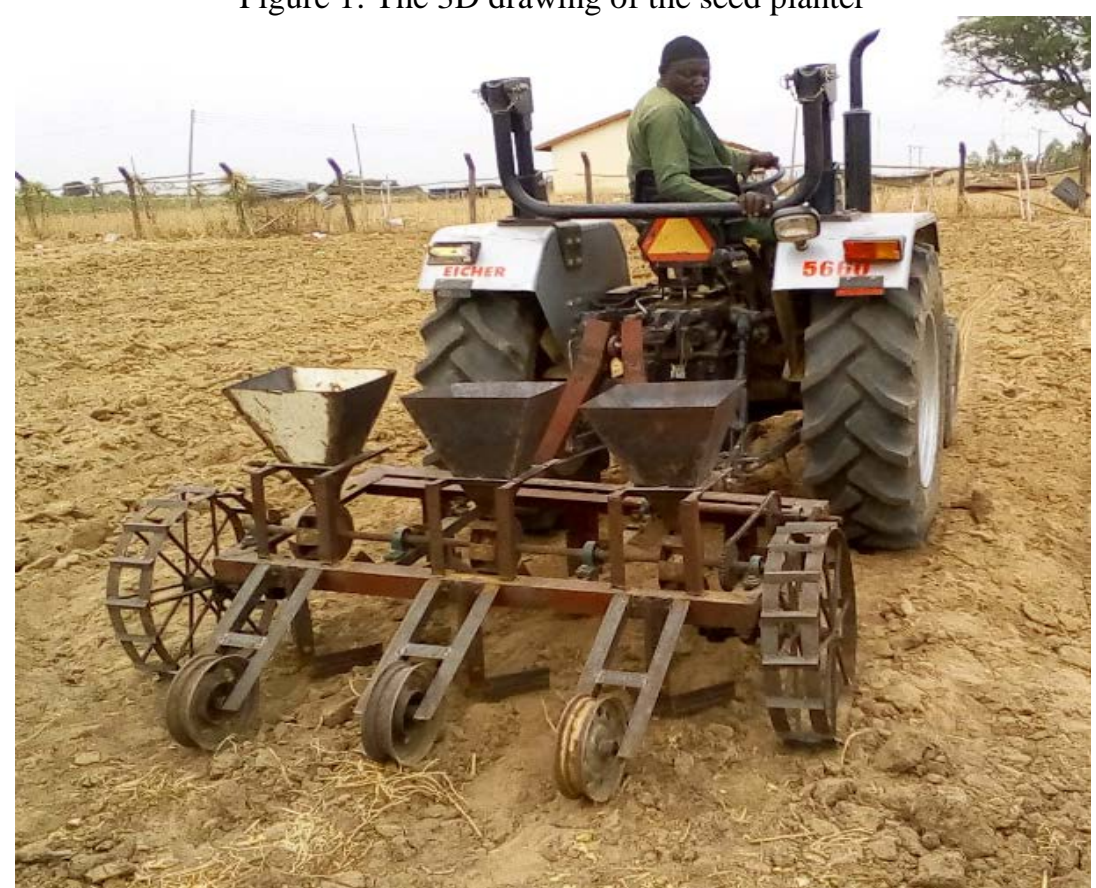

Plate 1: The fabricated seed planter 


\subsection{Testing of Machine}

A 90m x 90m field located at the Federal University of Technology, Minna farm site was ploughed and harrowed. The field was then sub divided into plots of 30m x 30m. Turmeric rhizomes were obtained from National Root Crops Research Institute (NRCRI) Nyanya Sub Station, Abuja. The rhizomes were cleaned and sorted into 30mm, 45mm and $60 \mathrm{~mm}$ lengths to determine the length which will give optimum performance. The planter was loaded with turmeric rhizome and then planted on the $30 \mathrm{~m} \times 30 \mathrm{~m}$ sub plots at three different operational speeds of $8 \mathrm{~km} / \mathrm{h}, 10 \mathrm{~km} / \mathrm{h}$ and $12 \mathrm{~km} / \mathrm{h}$ for each group. A three-variable, three level factorial design $(\mathrm{N}=33)$ provides the frame work for the experiment. The experimental design was a split-plot design according to the principle of factorial experiment. The three levels of speeds were assigned to the sub plot and the three levels of turmeric rhizome length were confounded to the split-plot. The data were subjected to Analysis of Variance (ANOVA) using expert design software and the following parameters were computed:

\subsubsection{Miss index}

Misses or skips are created when seed grooves fail to pick up and deliver seeds to the delivery funnels. Misses are counted along a randomly selected $15 \mathrm{~m}$ length of each planted row with the covering devices removed. The missing percentage is presented by an index called the miss index (MI) which is the percentage of spacing greater than 1.5times the theoretical spacing [11]

$M I=\frac{\mathrm{n}_{g}}{\mathrm{~N}} \times 100$

Where, ns is the number of skips, $\mathrm{N}$ is the Total number of spacing

\subsubsection{Field capacity of Planter}

The field capacity of the planter is the total area of land that was covered. It is expressed as the area of field covered in given time and was obtained as follows:

$C_{M}=\frac{A_{\mathrm{f}}}{\mathrm{T}}$

\section{RESULTS AND DISCUSSION}

\subsection{Miss index}

Table 1 shows the performance of the machine in terms of miss index. The result show that the miss percentage decreases with an increase in turmeric rhizome length. This observation does not agree with the findings of [12]. The results of the planter show that there was no steady pattern in the increase or decrease of miss index with increase in turmeric rhizome length and machine operational speed. The highest percentage turmeric rhizome miss index of 35\% was recorded for turmeric rhizome length of $30 \mathrm{~cm}$ at machine operational speed of $10 \mathrm{~km} / \mathrm{h}$ whereas the lowest percentage turmeric rhizome miss index of $15 \%$ was obtained for turmeric rhizome length of $60 \mathrm{~cm}$ at the machine operational speed of $12 \mathrm{~km} / \mathrm{h}$. The reason for this trend is because shorter rhizomes fall out easily as more than one turmeric rhizome tends to fall from the hopper to the metering system.

Table 1: Effect of machine operational speed on miss index for different lengths of turmeric rhizome

\begin{tabular}{|c|c|c|c|c|}
\hline \multirow[t]{2}{*}{ Levels } & \multirow{2}{*}{$\begin{array}{l}\text { Machine speed } \\
(\mathrm{km} / \mathrm{h})\end{array}$} & \multicolumn{3}{|c|}{ Percentage of miss index for different turmeric rhizome lengths (\%) } \\
\hline & & 30 & 45 & 60 \\
\hline \multirow[t]{3}{*}{1} & 8 & 30 & 30 & 25 \\
\hline & 10 & 35 & 20 & 15 \\
\hline & 12 & 30 & 25 & 20 \\
\hline \multirow[t]{3}{*}{2} & 8 & 30 & 35 & 15 \\
\hline & 10 & 35 & 15 & 20 \\
\hline & 12 & 30 & 25 & 20 \\
\hline \multirow[t]{3}{*}{3} & 8 & 35 & 25 & 20 \\
\hline & 10 & 25 & 20 & 20 \\
\hline & 12 & 35 & 30 & 20 \\
\hline
\end{tabular}

The result of the analysis variance (ANOVA) indicates that the machine operating speed has significant effect on the miss index of the turmeric rhizome prototype planter (at $\mathrm{P}<0.05$ ) while the grading of the turmeric rhizomes into different length has no significant effect on the miss index (at $\mathrm{P}>0.05$ ).

\subsection{Field capacity}

Results of test carried out to evaluate the planter's field capacity with respect different operational speeds are shown in 
table 2. The field capacities of planters depend on the operational speed. The results show that increase in machine operational speed resulted in an increase in field capacity of the machine for all turmeric rhizome lengths which agrees with [13]. It was observed that the field capacity of $0.63-0.65 \mathrm{ha} / \mathrm{h}$ was obtained for all turmeric rhizome lengths at the lowest operational speed of $8 \mathrm{~km} / \mathrm{h}$, while the highest field capacity of $0.95-0.96 \mathrm{ha} / \mathrm{h}$ was recorded for the various lengths of the turmeric rhizome at the highest machine speed of $12 \mathrm{~km} / \mathrm{h}$. Furthermore, the best planting field capacity of the turmeric rhizome planter was obtained when the rhizome length of $45 \mathrm{~cm}$ was planted at the operational speed of $12 \mathrm{~km} / \mathrm{h}$

\begin{tabular}{lllll}
\multicolumn{5}{c}{ Table 2: Effect of machine speed on field capacity for different lengths of turmeric rhizome } \\
\hline \multirow{2}{*}{$\begin{array}{l}\text { Levels } \\
\end{array}$} & $\begin{array}{l}\text { Machine speed } \\
(\mathrm{km} / \mathrm{h})\end{array}$ & \multicolumn{3}{l}{ Field capacity at different length of turmeric rhizome (ha/h) } \\
\hline 1 & 8 & 30 & 45 & 60 \\
& 10 & 0.64 & 0.65 & 0.63 \\
& 12 & 0.80 & 0.83 & 0.84 \\
& 8 & 0.96 & 0.96 & 0.95 \\
& 10 & 0.65 & 0.63 & 0.66 \\
3 & 12 & 0.84 & 0.82 & 0.84 \\
& 8 & 0.95 & 0.96 & 0.94 \\
& 10 & 0.66 & 0.63 & 0.64 \\
& 12 & 0.82 & 0.83 & 0.84 \\
\hline
\end{tabular}

\section{CONCLUSION}

The machine was successfully constructed and evaluated. The performance evaluation of the machine was carried out to assess the miss index and field capacity of the planter at three levels of operational speed of 8,10 and $12 \mathrm{~km} / \mathrm{h}$ and three levels of turmeric rhizome length of 30, 45 and $60 \mathrm{~mm}$. The machine operating speed has significant effect on the miss index of the turmeric rhizome prototype planter $(\mathrm{P}<0.05)$ while the grading of the turmeric rhizomes into different length has no significant effect on the miss index. There was no steady pattern in the increase or decrease of miss index with increase in turmeric rhizome length and machine operational speed. The field capacity of the planter mainly depended on operational speed. The size of the cane seeds (diameter and length) did not affect the field capacity of the machine. The highest capacity of $0.96 \mathrm{ha} / \mathrm{h}$ was recorded at the highest operational speed of $12 \mathrm{~km} / \mathrm{h}$ while the lowest field capacity of $0.63 \mathrm{ha} / \mathrm{h}$ was recorded at the lowest machine speed of $8 \mathrm{~km} / \mathrm{h}$.

\section{REFERENCES}

[1] Nwaekpe, J.O., Anyaegbunam, H.N., Okoye, B.C.and Asumugha, G.N., "Promotion of Turmeric for the Food/PharmaceuticalIndustry in Nigeria”, American Journal of Experimental Agriculture vol, 8, no. 6, pp. 35-341, 2015,

[2] FAO, “Turmeric- Post-Production Management”, 2004, http://www.fao.org/3/a-ax446e.pdf

[3] Sahdeo P. and Bharat B.A., "Turmeric, the Golden Spice”, 2011 https://www.ncbi.nlm.nih.gov/books/nbk9272/

[4] Balakrishnan K.V., "Postharvest technology and processing of turmeric: The Genus Curcuma”, Boca Raton, FL: CRC Press. pp. 193-256, 2007

[5] Ajit, k.S., Carroll, E.G., Roger P.R., Dennis, R.B., “Engineering Principles of Agricultural Machines”, Second Edition. ASABE Publication SO1M0206, 2006

[6] Olaoye J.O. and Bolufawi S.J., "Design, Fabrication and Performance of Multipopurse Row Planting Machine”, J. Sustain Agric. Environ”, vol, 3, no. 1, pp. 7-20, 2001

[7] Khan k., Mosses S.C, Kumar A., "The Design and Fabrication of Manually Operated Single Row Multi-Crops Planter”, Journal of Agriculture and Veterinary Science, vol, 8, no. 10, pp. 47-158, 2015

[8] Macmillian, R.H., "The Mechanics of Tractor-Implement Performance, Theory and Worked Examples”, a Text Book for Student and Engineers. R.H Machmillian, 2002.

[9] Khurmi, R.S., Gupta, J.K., “Machine Design, First Multicolour Edition”, Enrasia Publishing House (PVT) Ltd., Ram Nagar, New Delhi-110 055, 2005

[10] ASAE, “Standard Agricultural Machinery Management Data ASAE D 497”, 1999

[11] Kachman S. D and Smith J. A., "Alternative Measure of Accuracy in Plant Spacing for Planters Using Single Seed Metering”, vol. 38, no. 2, pp. 379-387, 2007

[12] Singh, T. P. and Gautam V., "Development and Performance Evaluation of a Gladiolus Planter in Field for Planting Corns”, International Journal of Agricultural and Biosystem Engineering, vol, 9, no. 12, pp. 1243-1248, 2015

[13] Khan k., Mosses S .C, Kumar A., “The Design and Fabrication of Manually Operated Single Row Multi-Crops Planter”, Journal of Agriculture and Veterinary Science, vol, 8, no. 10, pp. 147-158 